\title{
Quality changes and factors in Valencia oranges during storage under different temperatures
}

\author{
Yunhee Jo, Namhyeok Chung, Yaping Gao, Joong-Ho Kwon* \\ School of Food Science and Biotechnology, Kyungpook National University, Daegu 41566, Korea
}

\section{Valencia 오렌지의 저장온도에 따른 품질 변화 및 지표성분 확인}

\author{
조윤희 · 정남혁 · 까오야핑 · 권중호* \\ 경북대학교 식품공학부
}

\begin{abstract}
The effect of temperature on the quality and characteristics of Valencia oranges were studied during storage at low $\left(4^{\circ} \mathrm{C}, \mathrm{LT}\right)$ and room $\left(20^{\circ} \mathrm{C}, \mathrm{RT}\right)$ temperature. Hardness decreased beginning on the 10 th day of storage, regardless of temperature, and showed a more considerable reduction in the peel than the flesh. The total soluble solids (TSS) and titratable acidity (TA) decreased from the 30th day at LT and the 10th day at RT, but the TSS/TA ratio did not change during storage. The vitamin $C$ content decreased from the 20th day at LT and the 10th day at RT, and the total phenol content decreased from the 10th day of storage. In a sensory evaluation, the scores changed less for taste than for color and flavor during storage. The quality of Valencia oranges under two different temperatures was similar on the 30th day at LT and on the 10th day at RT. The TSS $(r=0.9453)$ and vitamin C content $(r=0.9104)$ were highly related to sensory properties. These results suggested that TSS and vitamin $C$ are potential indicators of quality for the selection of Valencia oranges during storage.
\end{abstract}

Key words : Valencia orange, storage temperature, quality change, quality factor, vitamin $\mathrm{C}$

\section{서 론}

오렌지(Citrus sinensis)는 운향과 귤속 과일 중 하나로 비타민 $\mathrm{C}$ 의 함량이 풍부하고, carotenoid, flavone 등 다양한 phytochemical을 포함하고 있다(1). 미국에서 가장 많이 생 산되는 과일 중 하나인 오렌지는 생산지역에 따라 그 특징 과 용도가 다양하다(2). 캘리포니아 산 오렌지는 주로 생과 로 이용되는 반면 플로리다산 오렌지는 대부분 주스 등의 가공용으로 이용되는데, 이는 캘리포니아 산 오렌지가 껍 질이 두껍고 외관이 좋아 유통에 유리하고 소비자에게 선호 되기 때문이다. 캘리포니아 주에서는 Navel 품종과 Valencia 품종이 주로 재배되고 있으며, 5월에서 10 월 사이

*Corresponding author. E-mail : jhkwon@knu.ac.kr Phone : 82-53-950-5775, Fax : 82-53-950-6772

Received 15 June 2015; Revised 25 September 2015; Accepted 30 September 2015.

Copyright (c) The Korean Society of Food Preservation. All rights reserved.
주로 생산되는 Valencia 오렌지는 씨가 있으면서 껍질이 얇은 품종으로, 향기가 풍부하고 즙의 당도가 높아 과즙 음료의 원료로 많이 사용된다(3).

미숙한 과일이 먹기 좋은 상태로 되어가는 성숙과정을 거치면 과일은 노화되면서 품질저하 과정으로 들어선다. 수확된 농산물은 호흡작용으로 열을 방출하기 때문에 주위 온도보다 높은 상태로 되고, 호흡작용 외에 수분의 증산도 이루어져 필름 및 상자로 포장된 농산물의 습도는 거의 $100 \% \mathrm{RH}$ 의 상태가 된다. 이처럼 고온다습한 상태가 유지 되면 변색, 연화, 시들음 등의 품질악화 또는 곰팡이 및 세균번식에 의한 부패가 촉진된다. 오렌지는 성숙과 숙성 과정에서 호흡의 변화가 거의 없는 비급등형(non-climacteric) 과일이나(4), 저장온도는 농산물의 호흡작용 및 미생물 번 식과 밀접한 연관이 있고, 저장 중 발생하는 조직연화 현상 은 저장온도가 높을 때 급속히 진행되므로 이를 억제하기 위해서는 정확한 온도관리가 필수적이다(5). 과일에서 일 어나는 여러 가지 생리적 반응은 온도의 변화에 큰 변화를 받으며, 온도가 낮을수록 반응속도가 느려진다. 온도가 낮 
아질 때 생물활성이 감소하는 원리를 $\mathrm{Q}_{10}$ 이론이라 하는데 $\mathrm{Q}_{10}$ 값은 온도가 $10^{\circ} \mathrm{C}$ 낮아지거나 상승할 때 생물 대사작용 의 변화율을 나타내며, 과실의 저장온도에 따른 손실률이 나 저장기간을 예측하는 지표로 사용된다.

오렌지는 당도가 높고, 향이 좋으며, 색이 화려한 상품이 선호되지만, 장기간 저장 시 풍미의 변화가 쉽게 일어나므 로 가장 적합한 저장온도를 고르는 것은 매우 중요하다. 국산 귤속 과일인 온주밀감의 경우 수확 후 저장 시 품질 안정성 대한 연구(6-8)가 활발히 이루어진 반면, 수입 오렌 지의 경우 주스와 관련된 연구 $(9,10)$ 가 일부 수행되었을 뿐 저장 안정성에 대한 연구는 거의 진행되지 않았다. 이에 본 연구에서는 수입 오렌지 중 여름 계절에 유통되는 Valencia 품종의 신선도 유지기간에 대한 기초자료를 확보 하고자, 온도관리가 오렌지의 품질과 저장성에 미치는 영향 을 평가하고 이와 관련된 품질인자를 확인하고자 하였다.

\section{재료 및 방법}

\section{실험재료}

수입 오렌지 중 여름 계절에 유통되는 Valencia 품종(CA, USA)을 대상으로 상품적 선호도가 큰 중간 크기의 오렌지 를 선택하였다. 2014년 7월 수확 후 냉장설비를 갖춘 선박 으로 운송되어 저온조건으로 보관된 오렌지를 8 월 대구의 수입과일 도매마트에서 구매하였다. 약 $18 \mathrm{~kg}$ 의 포장상자 당 $88 \pm 5$ 과의 중과 $(190 \sim 220 \mathrm{~g})$ 를 시료로 하여, 저장온도에 따라 4반복으로 설정하였다. 오렌지는 두께 $0.05 \mathrm{~mm}$ 의 폴 리에틸렌 필름에 10 개씩 담아 포장박스 상태로 저온 $\left(4^{\circ} \mathrm{C}\right)$ 과 상온 $\left(20^{\circ} \mathrm{C}\right)$ 에 30 일간 보관하면서 실험에 사용하였다.

\section{물리적 특성 분석}

오렌지의 부패율과 중량감소율은 임의로 선정한 100 개 의 과일을 10 개씩 폴리에틸렌 필름으로 포장하여 저장 동 안의 변화로 관찰하였다. 부패율은 꼭지 썩음, 껍질 흑변 및 곰팡이 발생을 부패로 판단하여 백분율(\%)로 나타내었 고, 중량감소율은 초기 중량에 대한 감소를 백분율(\%)로 나타내었다. 껍질 두께는 caliper(CD-150PX, Mitutoyo, Kanagawa, Japan)를 이용하였고, 경도는 rheometer(Compac100II, Sun Scientific Co., Ltd., Tokyo, Japan)를 이용하여 껍질 제거 전후 서로 다른 적도부위를 측정하였다. 색도는 색차계(CM-3600d, Konica Minolta, Osaka, Japan)를 이용하 여 껍질 및 과육 표면을 측정하고, 명도( $\mathrm{L}^{*}$, lightness), 적색 도 (a*, redness) 및 황색도 $\left(\mathrm{b}^{*}\right.$, yellowness) 값으로 나타내었 다. 껍질두께, 경도 및 색도는 10 회 반복 측정 후 최대 및 최소값을 제외하였다.

\section{화학적 특성 분석}

오렌지를 5 개씩 무작위로 선택한 후 껍질을 제거하고
균질기(HR-2870, Philips, Amsterdam, Netherlands)로 착즙 하여 지름 0.4 0.6 mm의 체(sieve)를 통과시킨 후 이를 분석 에 사용하였다. 과즙의 $\mathrm{pH}$ 측정을 위해 $\mathrm{pH}$ meter(Orion 3 star, Thermoelectron Co., Beverly, USA)를 사용하였고, 가용성 고형분(total soluble solids, TSS) 함량은 굴절당도계 (Master-M, Atago, Tokyo, Japan)를 사용하였으며, 적정산도 (titratable acidity, TA)는 $\mathrm{pH} 8.35$ 8.40가 될 때까지 $0.1 \mathrm{~N}$ $\mathrm{NaOH}$ 용액으로 적정하여 구연산 함량(\%)으로 환산하였 다. 당/산비(TSS/TA ratio)는 당도와 적정산도의 비로 나타 내었다. 오렌지 과즙에 대한 환원당 함량은 dinitrosalicylic $\operatorname{acid}(\mathrm{DNS})$ 방법(11)에 따라 측정하였다. 희석한 오렌지 시 료 $1 \mathrm{~mL}$ 에 DNS 시약 $1 \mathrm{~mL}$ 를 혼합한 후 $95^{\circ} \mathrm{C}$ 에서 10 분간 가열하고 증류수 $3 \mathrm{~mL}$ 를 첨가한 후 분광광도계(Optizen 2120UV, Mecasys, Co., Ltd., Daejeon, Korea)를 이용하여 $520 \mathrm{~nm}$ 에서 흡광도를 측정하였다. 표준곡선 작성에는 glucose(Sigma Co., MO, USA)를 사용하였다.

\section{비타민 C 및 총 페놀 함량}

오렌지의 비타민 C 함량 측정을 위해 hydrazine 비색법 (12)에 따라 과육 $10 \mathrm{~g}$ 에 $5 \%$ 메타인산용액 $50 \mathrm{~mL}$ 를 가하여 마쇄하고 여과하였다. 분광광도계(Optizen 2120UV, Mecasys, Co., Ltd.)를 이용하여 $525 \mathrm{~nm}$ 에서 흡광도를 측정하였고, 표준곡선 작성에는 ascorbic acid(Sigma Co., MO, USA)를 사용하였다. 오렌지 과즙에 대한 총 페놀 함량은 Folin-Ciocalteu 방법(13)에 따라 시료 $0.2 \mathrm{~mL}$ 에 증류수 1.8 $\mathrm{mL}$ 를 첨가하고 phenol reagent $0.2 \mathrm{~mL}$ 를 혼합하여 6분간 반응시킨 후 $7 \% \mathrm{Na}_{2} \mathrm{CO}_{3} 2 \mathrm{~mL}$ 를 혼합하여 $750 \mathrm{~nm}$ 에서 흡광도를 측정하였다. 표준곡선 작성에는 gallic acid(Sigma Co., MO, USA) 용액을 사용하였고, 시료의 총 페놀 함량은 $\mathrm{mg}$ gallic acid equivalents(GAE)/100 $\mathrm{g}$ 로 나타내었다.

\section{기호도 평가}

식품관련 전공의 22 30세 학생 40명을 대상으로 오렌지 기호도에 대한 예비 훈련 후 평가를 실시하였다. 각 저장고 에서 15 개의 오렌지를 무작위로 취하였고, 저장온도에 따 른 기호도 차이를 최소화하기 위해 $10^{\circ} \mathrm{C}$ 온도에서 2 시간가 량 보관 후 평가에 사용하였다. 9점 채점법(14)으로 과일에 대해 색, 향, 전반적 기호도(1점, 매우 나쁘다; 9점, 매우 좋다, 5 점, 가식한계점)와 단맛, 신맛에 대한 강도(1점, 매우 약하다; 9점, 매우 강하다)를 평가하였다. 각 과일을 종경으 로 절단(약 $50 \mathrm{~g})$ 하고 같은 접시에 담은 후 임의의 세 자리 숫자로 coding하여 평가를 진행하였고, 모든 평가에서 한 개의 시료를 평가한 후 반드시 물로 입안을 헹구어 낸 후 다음 평가를 진행하도록 하였다.

\section{통계분석}

실험결과에 대한 통계분석은 statistical analysis system 
(SAS)(15)를 이용하여 분산분석(ANOVA)을 실시하여 Duncan's multiple range test로 $\mathrm{p}<0.05$ 수준에서 유의성을 검정하였다. 또한 이화학적 및 기호도 특성 간의 상관관계 는 Pearson's correlation analysis를 통하여 분석하였다.

\section{결과 및 고찰}

\section{저장온도에 따른 물리적 특성 변화}

저장에 따른 오렌지의 물리적 특성 중 부패율, 중량감소 율, 껍질 두께의 변화를 Table 1 에 나타내었다. 저장온도에 따른 오렌지 부패율 관찰 결과, 저온에서는 30 일 동안 과일 의 부패가 발생하지 않은데 비해 상온에서는 저장 20 일부 터 일부 과일에서 꼭지 썩음, 껍질 흑변, 곰팡이 발생 등의 부패 현상이 나타나기 시작하여 이 후 큰 폭으로 진행되었

Table 1. Physical properties of Valencia oranges during storage at $4^{\circ} \mathrm{C}$ and $20^{\circ} \mathrm{C}$

\begin{tabular}{|c|c|c|c|c|c|}
\hline \multirow{2}{*}{ Properties } & \multirow{2}{*}{$\begin{array}{c}\text { Temp. } \\
\left({ }^{\circ} \mathrm{C}\right)\end{array}$} & \multicolumn{4}{|c|}{ Period (days) } \\
\hline & & 0 & 10 & 20 & 30 \\
\hline \multirow{2}{*}{$\begin{array}{l}\text { Decay ratio } \\
(\%)\end{array}$} & 4 & - & - & - & - \\
\hline & 20 & & - & $6.00 \pm 2.83^{1)}$ & $24.00 \pm 5.66$ \\
\hline \multirow{2}{*}{$\begin{array}{l}\text { Weight loss } \\
\quad(\%)\end{array}$} & 4 & $0.00 \pm 0.00^{c}$ & $0.06 \pm 0.03^{c}$ & $0.24 \pm 0.08^{\mathrm{bc}}$ & $0.32 \pm 0.17^{\mathrm{bc}}$ \\
\hline & 20 & & $0.77 \pm 0.46^{\mathrm{b}}$ & $1.98 \pm 0.27^{\mathrm{a}}$ & $2.16 \pm 0.04^{\mathrm{a}}$ \\
\hline \multirow{2}{*}{$\begin{array}{l}\text { Peel thickness } \\
\text { (mm) }\end{array}$} & 4 & $5.72 \pm 0.78^{\mathrm{a}}$ & $5.13 \pm 0.66^{b}$ & $4.61 \pm 0.71^{\text {bed }}$ & $4.53 \pm 0.58^{\text {cd }}$ \\
\hline & 20 & & $4.73 \pm 0.40^{\mathrm{bc}}$ & $4.08 \pm 0.59^{\mathrm{de}}$ & $3.81 \pm 0.49^{\mathrm{e}}$ \\
\hline \multicolumn{6}{|c|}{ Color value (peel) } \\
\hline \multirow[t]{2}{*}{$L^{*}$ value } & 4 & $68.58 \pm 2.03^{\mathrm{a}}$ & $69.16 \pm 1.31^{a}$ & $68.71 \pm 1.86^{\mathrm{a}}$ & $68.52 \pm 1.16^{\mathrm{a}}$ \\
\hline & 20 & & $69.30 \pm 1.48^{\mathrm{a}}$ & $67.92 \pm 1.91^{\mathrm{a}}$ & $65.16 \pm 4.80^{b}$ \\
\hline \multirow[t]{2}{*}{$a^{*}$ value } & 4 & $4.72 \pm 3.37^{b}$ & $6.61 \pm 2.55^{\mathrm{ab}}$ & $7.42 \pm 2.88^{\mathrm{ab}}$ & $8.55 \pm 1.84^{\mathrm{a}}$ \\
\hline & 20 & & $6.46 \pm 1.87^{\mathrm{ab}}$ & $5.91 \pm 2.44^{\mathrm{ab}}$ & $6.31 \pm 1.75^{\mathrm{ab}}$ \\
\hline \multirow[t]{2}{*}{$b^{*}$ value } & 4 & $54.27 \pm 3.19^{\mathrm{a}}$ & $51.48 \pm 3.12^{\mathrm{a}}$ & $51.45 \pm 1.37^{\mathrm{a}}$ & $51.26 \pm 2.26^{\mathrm{a}}$ \\
\hline & 20 & & $45.08 \pm 1.78^{b}$ & $45.52 \pm 5.75^{\mathrm{b}}$ & $38.16 \pm 8.41^{\mathrm{c}}$ \\
\hline \multirow[t]{2}{*}{$\Delta \mathrm{E}$ value } & 4 & $0.00 \pm 0.00$ & $5.01 \pm 1.65$ & $4.86 \pm 2.01$ & $5.26 \pm 2.31$ \\
\hline & 20 & & $9.66 \pm 1.70$ & $9.60 \pm 5.19$ & $17.13 \pm 8.61$ \\
\hline \multicolumn{6}{|c|}{ Color value (flesh) } \\
\hline \multirow[t]{2}{*}{$\mathrm{L}^{*}$ value } & 4 & $52.95 \pm 2.66^{\mathrm{ab}}$ & $51.66 \pm 1.69^{\mathrm{abc}}$ & $49.26 \pm 1.16^{\mathrm{d}}$ & $50.70 \pm 1.60^{\mathrm{cd}}$ \\
\hline & 20 & & $53.62 \pm 1.94^{\mathrm{a}}$ & $51.36 \pm 2.26^{\text {bed }}$ & $50.88 \pm 1.96^{\mathrm{bcd}}$ \\
\hline \multirow[t]{2}{*}{$a^{*}$ value } & 4 & $0.75 \pm 0.56^{\mathrm{ab}}$ & $-0.26 \pm 0.53^{\text {cd }}$ & $1.04 \pm 0.45^{\mathrm{a}}$ & $0.15 \pm 0.25^{\mathrm{bc}}$ \\
\hline & 20 & & $0.52 \pm 0.65^{\mathrm{ab}}$ & $-0.68 \pm 0.44^{\mathrm{d}}$ & $-0.28 \pm 1.52^{\mathrm{cd}}$ \\
\hline \multirow[t]{2}{*}{$\mathrm{b}^{*}$ value } & 4 & $15.65 \pm 2.04^{\mathrm{ab}}$ & $14.19 \pm 1.71^{\mathrm{bcd}}$ & $14.88 \pm 1.31^{\text {abc }}$ & $12.71 \pm 1.21^{\mathrm{d}}$ \\
\hline & 20 & & $13.65 \pm 1.02^{\mathrm{cd}}$ & $15.36 \pm 1.38^{\mathrm{ab}}$ & $16.23 \pm 1.64^{\mathrm{a}}$ \\
\hline \multirow[t]{2}{*}{$\Delta \mathrm{E}$ value } & 4 & $0.00 \pm 0.00$ & $2.90 \pm 1.38$ & $4.06 \pm 0.87$ & $4.03 \pm 1.27$ \\
\hline & 20 & & $2.86 \pm 1.01$ & $3.10 \pm 1.22$ & $3.57 \pm 0.90$ \\
\hline
\end{tabular}

${ }^{1)}$ Mean \pm SD ( $\mathrm{n}=3$ ). Means with different superscripts within the row are significantly different at $\mathrm{p}<0.05$ based on Duncan's multiple range test.
다. 수입 오렌지는 저장 중 호흡률을 낮추기 위하여 waxcoating을 하는데, Yang 등(16)은 wax-coating의 경우 저장 후기 생리적 장해로 인한 부패 유발 가능성을 보고하였다. 한편, $\mathrm{Kim}$ 등(17)은 온주밀감의 저장에서 상온저장에 비해 저온저장에서 부패율을 줄일 수 있었으며, 감귤 저장에서 온도뿐 아니라 저장고 내의 온도편차도 고려해야 한다고 보고하였다. 수확 농산물의 저장/유통 중 중량감소는 호흡 작용을 통한 기질의 분해 및 증산작용에 의해 발생한다(18). 오렌지의 중량감소율은 저온에서 30 일 동안 $0.06 ~ 0.32 \%$ 정도로 확인되었으나, 상온에서 0.77 2.16\% 정도로 비교적 높게 나타났다. 한편, 오렌지 중량감소율의 경우 저온에서 의 30 일 저장은 상온에서의 10 일 저장과 유의적인 차이가 없었다 $(\mathrm{p}<0.05)$. 과일의 껍질 두께는 생과의 식미에 영향을 미칠 뿐 아니라, 가공 산업에서 중요한 과육율과 직접적인 관계가 있다(19). Valencia 오렌지의 껍질 두께는 저장 초기 $5.72 \mathrm{~mm}$ 를 나타내었으나, 저장 30 일 후 $4.53 \mathrm{~mm}$ (저온) 및 $3.81 \mathrm{~mm}$ (상온)로 감소하였다. 한편, 저온에서의 30 일 저장 은 상온에서의 20 일 저장과 유의적인 차이가 없는 것으로 확인되었다 $(\mathrm{p}<0.05)$.

오렌지 경도는 껍질을 포함한 과일의 형태와 껍질을 제 거한 과육의 형태로 구분하여 측정하였다. Fig. 1 과 같이 오렌지 껍질의 유무와 관계없이 과일과 과육 모두 저온 및 상온저장 동안 경도가 감소함을 확인할 수 있었다. 한편, 껍질을 포함한 과일의 경우 저온에 비해 상온저장에서 경도 감소율이 뚜렷이 나타난 반면, 껍질을 제거한 과육의 경우 저장 20 일 동안 경도 감소에 대한 온도의 영향이 크지 않았 으나 저장 30 일에는 온도에 따른 유의적인 차이를 나타내 었다 $(\mathrm{p}<0.05)$. 이상의 결과, Valencia 오렌지의 경우 저장에 따른 경도 감소는 주로 껍질에서 나타나는 현상임을 확인할 수 있었고, 껍질을 포함한 과일의 경도는 저온 30 일 저장시 료가 상온 10 일 저장시료보다 유의적으로 단단한 것으로 확인되었다 $(\mathrm{p}<0.05)$. 과육의 충실도, 껍질의 두께와 단단함, 과육과 껍질의 밀착도 등은 감귤의 경도에 영향을 미치는 요인이며, 일반적으로 경도가 높을수록 저장성이 있는 것 으로 보고되어 있다(20).

오렌지의 색도 측정을 위해 과일의 껍질부위와 과일의 적도를 절단한 과육부위로 구분하여 각각의 표면을 측정한 후 기계적 색도로 나타내었다(Table 1). 껍질의 경우 저장 초기 $\mathrm{L}^{*}$ 값(명도)과 $\mathrm{a}^{*}$ 값(적색도)은 68.58 및 4.72 를 나타내 었고, 이들은 각각 상온 30 일 및 저온 30 일 저장시료에서만 유의적인 변화를 나타내었다( $p<0.05)$, 한편 껍질의 $b^{*}$ 값(황 색도)은 저온저장 동안 변화가 없었으나 상온저장의 경우 유의적으로 감소하였으며 $(\mathrm{p}<0.05)$, 그 결과 $\Delta \mathrm{E}$ 값(전반적 색차)은 저온저장에서의 4.86 5.26에 비해 상온저장에서 9.60 17.13까지 크게 상승하였다. 과육의 경우 $\mathrm{L}^{*}, \mathrm{a}^{*}, \mathrm{~b}^{*}$ 값은 저장온도와 기간에 따른 유의적인 차이를 나타내었으 나 일정한 경향은 확인되지 않았으며, $\Delta \mathrm{E}$ 값에 대한 온도의 
영향은 크지 않은 것으로 확인되었다.

이상의 결과, Valencia 오렌지의 물리적 특성 중 부패율, 중량감소율 및 껍질의 $\mathrm{L}^{*}, \mathrm{~b}^{*}$ 값은 저온저장 30 일 동안 품질 의 유의적인 차이를 보이지 않았고 $(\mathrm{p}<0.05)$, 전반적인 물리 적 특성은 저온저장 30 일의 품질이 상온저장 10 일과 유사 한 것으로 확인되었다.
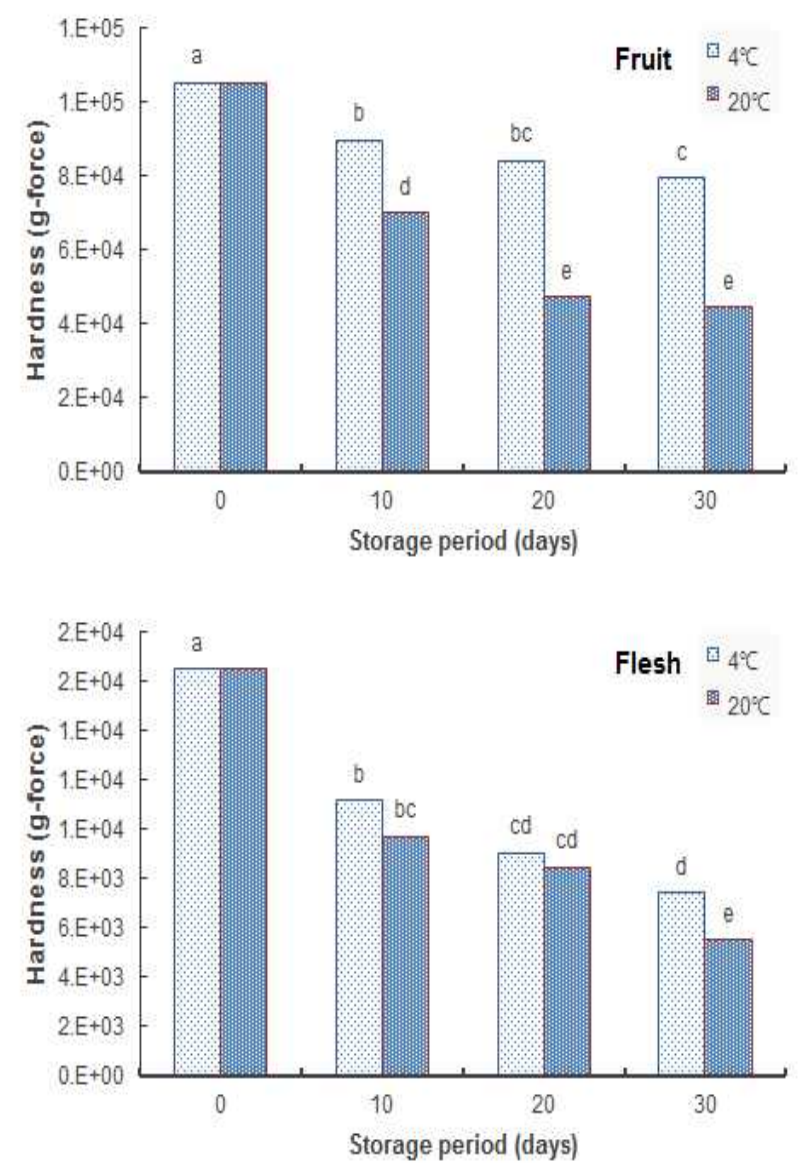

Fig. 1. Changes in hardness of Valencia or anges during storage at $4^{\circ} \mathrm{C}$ and $20^{\circ} \mathrm{C}$.

Means with different superscripts within the bar are significantly different at $p<0.05$ based on Duncan's multiple range test.

\section{저장온도에 따른 화학적 특성 변화}

Valencia 오렌지의 화학적 특성에 대한 저장온도의 영향 은 Table 2와 같다. 오렌지의 $\mathrm{pH}$ 는 3.77 4.07 범위를 나타내 었고, 온도에 관계없이 저장 30 일 째에 유의적으로 감소하 였다 $(\mathrm{p}<0.05)$. 가용성 고형분 함량과 적정산도는 각각 $10.13 \sim 12.27^{\circ}$ Brix 및 0.78 0.89\% 범위를 나타내었고, 저온 저장의 경우 30 일에 상온저장의 경우 10 일 째부터 유의적 으로 감소하였다(p<0.05). 당/산비는 당 함량과 산 함량의 비율로서 과일 품질판정에 중요한 지표로 사용되며, 그 비 가 높을수록 기호도가 높아진다(21). 과즙의 당/산비는 저 장 초기 13.76 이었고, 저온 및 상온저장 동안 12.85 13.84
범위로 모두 오차 범위 내에서 증감을 반복하여 유의적인 차이는 보이지 않았다. 환원당 함량은 저온저장의 경우 유 의적인 차이를 보이지 않았고, 상온의 경우 저장 30 일에 유의적으로 감소하였다 $(\mathrm{p}<0.05)$. 한편, 과일의 당 함량은 성숙과정이나 저장기간 동안 가수분해에 의해 증가되기도 하고 호흡기질로 사용되어 감소하기도 하는데, 비급등형인 감귤류의 경우 저장기간 중에도 계속되는 호흡작용으로 내용성분의 변화가 일어나는 것으로 알려져 있다(22).

과일은 여러 식물 중 항산화능이 우수한 천연 자원으로 특히 유리기를 소거하는 능력이 탁월한 것으로 보고되어 왔으며, 이들 성분에는 항산화 비타민과 폴리페놀 성분이 관련된다 $(23,24)$. 오렌지의 비타민 C 함량은 저온의 경우 저장 20 일부터 상온의 경우 10 일부터 유의적으로 감소하였 고, 총 페놀함량은 온도에 상관없이 모두 저장 10 일부터 감소하였다( $\mathrm{p}<0.05)$. 한편, 저온에서 30 일 저장된 오렌지의 비타민 $\mathrm{C}$ 와 총 페놀함량은 상온 20 일의 시료와 유의적인 차이가 없는 것으로 확인되었다. Koh 등(25)은 온주밀감의 저장에 따른 비타민 C 함량 변화에서 저장기간에 따른 감소 와 더불어 저온보다 상온에서의 현저한 감소를 보고하여 본 연구의 결과를 잘 뒷받침하였다.

이상의 결과, Valencia 오렌지의 화학적 특성 중 당/산비 는 저장 30 일 동안 품질의 유의적인 차이를 보이지 않았고, 전반적인 화학적 특성은 저온저장 30 일의 품질이 상온저장 20 일과 유사한 것으로 확인되었다.

Table 2. Chemical properties of Valencia oranges during storage at $4^{\circ} \mathrm{C}$ and $20^{\circ} \mathrm{C}$

\begin{tabular}{|c|c|c|c|c|c|}
\hline \multirow{2}{*}{ Properties } & \multirow{2}{*}{$\begin{array}{c}\text { Temp. } \\
\left({ }^{\circ} \mathrm{C}\right)\end{array}$} & \multicolumn{4}{|c|}{ Period (days) } \\
\hline & & 0 & 10 & 20 & 30 \\
\hline \multirow[t]{2}{*}{ pH } & 4 & $4.03 \pm 0.03^{\text {al) }}$ & $4.05 \pm 0.04^{\mathrm{a}}$ & $4.03 \pm 0.09^{\mathrm{a}}$ & $3.80 \pm 0.08^{\mathrm{b}}$ \\
\hline & 20 & & $4.07 \pm 0.03^{\mathrm{a}}$ & $4.05 \pm 0.02^{\mathrm{a}}$ & $3.77 \pm 0.03^{b}$ \\
\hline \multirow{2}{*}{$\begin{array}{l}\text { Total soluble solids } \\
\text { (TSS, }{ }^{\circ} \text { Brix) }\end{array}$} & 4 & $12.27 \pm 0.21^{\mathrm{a}}$ & $11.90 \pm 0.19^{\mathrm{a}}$ & $11.87 \pm 0.23^{\mathrm{a}}$ & $10.70 \pm 0.44^{\text {bc }}$ \\
\hline & 20 & & $10.90 \pm 0.60^{\mathrm{b}}$ & $10.67 \pm 0.06^{\mathrm{bc}}$ & $10.13 \pm 0.12^{\mathrm{c}}$ \\
\hline \multirow{2}{*}{$\begin{array}{l}\text { Titratable acidity } \\
\text { (TA, \%) }\end{array}$} & 4 & $0.89 \pm 0.02^{\mathrm{a}}$ & $0.88 \pm 0.02^{\mathrm{ab}}$ & $0.86 \pm 0.03^{\text {abc }}$ & $0.80 \pm 0.02^{\mathrm{de}}$ \\
\hline & 20 & & $0.85 \pm 0.02^{\text {bdd }}$ & $0.83 \pm 0.04^{\mathrm{cd}}$ & $0.78 \pm 0.01^{\mathrm{e}}$ \\
\hline \multirow[t]{2}{*}{ TSS/TA ratio } & 4 & $13.76 \pm 0.58^{\mathrm{a}}$ & $13.48 \pm 0.12 \mathrm{a}$ & $13.84 \pm 0.47 \mathrm{a}$ & $13.37 \pm 0.79 \mathrm{a}$ \\
\hline & 20 & & $12.85 \pm 0.37^{\mathrm{e}}$ & $12.85 \pm 0.62^{\mathrm{a}}$ & $12.93 \pm 0.30^{\mathrm{a}}$ \\
\hline \multirow{2}{*}{$\begin{array}{l}\text { Reducing sugar } \\
(\%)\end{array}$} & 4 & $4.10 \pm 0.38^{\mathrm{ab}}$ & $3.84 \pm 0.05^{\mathrm{ab}}$ & $3.60 \pm 0.04^{\mathrm{bc}}$ & $3.63 \pm 0.07^{\mathrm{bc}}$ \\
\hline & 20 & & $3.61 \pm 0.30^{\mathrm{bc}}$ & $3.45 \pm 0.17^{\mathrm{bc}}$ & $3.22 \pm 0.02^{\mathrm{c}}$ \\
\hline \multirow{2}{*}{$\begin{array}{l}\text { Vitamin } C \\
(\mathrm{mg} \%)\end{array}$} & 4 & $43.70 \pm 1.15^{\mathrm{a}}$ & $40.59 \pm 2.18^{\mathrm{ab}}$ & $37.77 \pm 1.74^{\mathrm{bc}}$ & $36.45 \pm 1.47^{\mathrm{cd}}$ \\
\hline & 20 & & $34.76 \pm 3.10^{\mathrm{cd}}$ & $34.23 \pm 2.27^{\mathrm{cd}}$ & $33.30 \pm 3.64^{d}$ \\
\hline \multirow{2}{*}{$\begin{array}{c}\mathrm{TPC}^{2)} \\
(\mathrm{mg} \mathrm{GAE} / 100 \mathrm{~mL})\end{array}$} & 4 & $108.23 \pm 1.79^{a}$ & $101.01 \pm 3.36^{b}$ & $93.55 \pm 2.12^{\mathrm{cd}}$ & $91.06 \pm 3.77^{\mathrm{de}}$ \\
\hline & 20 & & $96.34 \pm 2.74^{\mathrm{c}}$ & $91.98 \pm 3.97^{\mathrm{d}}$ & $87.76 \pm 3.26^{\mathrm{e}}$ \\
\hline
\end{tabular}

${ }^{1)}$ Mean \pm SD ( $n=3$ ). Means with different superscripts within the row are significantly different at $\mathrm{p}<0.05$ based on Duncan's multiple range test.

${ }^{2)} \mathrm{TPC}$, total phenolic compounds. 


\section{저장온도에 따른 기호도 변화}

오렌지에 대한 관능평가 결과는 Table 3과 같고, 상온 시료는 저장 20 일부터 상품성 없이 가식이 불가능한 상태 로 판단되어 평가에서 제외하였다. 색의 관능평점은 저장 초기 7.37점이었으나 저장 10 일차부터 저장온도에 관계없 이 유의적으로 감소하여 저장기간 동안 5.93 6.65점을 나타 내었다 $(\mathrm{p}<0.05)$. 상온 저장 시료의 색에 대한 관능평점 저하 는 기계적 색도(황색도)의 감소와 일치하는 경향이었다. 향에 대한 관능평점 역시 저장 초기 7.10점이었으나 저장 10 일차부터 온도에 상관없이 유의적으로 감소하여 저장 동안 5.31 6.31점 범위를 나타내었다 $(\mathrm{p}<0.05)$. 단맛과 신맛 은 저장 초기 각각 6.70 및 6.40점을 나타내었으나 저온의 경우 저장 30 일, 상온의 경우 저장 10 일에 각각 유의적으로 감소하였다 $(\mathrm{p}<0.05)$. 이는 Table 2 의 가용성 고형분 함량 및 적정산도의 결과와 유사한 경향을 나타내었다. 오렌지 의 맛에 대한 관능평점은 색과 향에 평점에 비해 저장기간

Table 3. Sensory properties of Valencia oranges during storage at $4{ }^{\circ} \mathrm{C}$ and $20^{\circ} \mathrm{C}$

\begin{tabular}{cccccc}
\hline \multirow{2}{*}{ Properties } & \multirow{2}{*}{$\begin{array}{c}\text { Temp. } \\
\left.{ }^{\circ} \mathrm{C}\right)\end{array}$} & 0 & 10 & 20 & 30 \\
\hline \multirow{2}{*}{ Color } & 4 & $7.37 \pm 0.87^{\mathrm{al}}$ & $6.65 \pm 0.68^{\mathrm{b}}$ & $6.55 \pm 1.05^{\mathrm{bc}}$ & $5.93 \pm 1.11^{\mathrm{cd}}$ \\
& 20 & $7.37 \pm 0.87^{\mathrm{a}}$ & $5.93 \pm 1.36^{\mathrm{cd}}$ & - & - \\
\hline \multirow{2}{*}{ Aroma } & 4 & $7.10 \pm 0.83^{\mathrm{a}}$ & $6.31 \pm 1.20^{\mathrm{b}}$ & $6.27 \pm 1.16^{\mathrm{b}}$ & $5.72 \pm 0.91^{\mathrm{bc}}$ \\
& 20 & $7.10 \pm 0.83^{\mathrm{a}}$ & $5.31 \pm 1.15^{\mathrm{c}}$ & - & - \\
\hline \multirow{2}{*}{ Sweet taste } & 4 & $6.70 \pm 1.35^{\mathrm{a}}$ & $6.38 \pm 0.92^{\mathrm{a}}$ & $6.39 \pm 1.18^{\mathrm{a}}$ & $5.48 \pm 1.07^{\mathrm{b}}$ \\
& 20 & $6.70 \pm 1.35^{\mathrm{a}}$ & $5.76 \pm 1.13^{\mathrm{b}}$ & - & - \\
\hline \multirow{2}{*}{ Sour taste } & 4 & $6.40 \pm 0.88^{\mathrm{a}}$ & $6.04 \pm 0.94^{\mathrm{a}}$ & $6.03 \pm 1.03^{\mathrm{a}}$ & $4.97 \pm 1.30^{\mathrm{b}}$ \\
& 20 & $6.40 \pm 0.88^{\mathrm{a}}$ & $5.31 \pm 1.09^{\mathrm{b}}$ & - & - \\
\hline \multirow{2}{*}{ Overall } & 4 & $6.83 \pm 0.97^{\mathrm{a}}$ & $6.50 \pm 1.05^{\mathrm{a}}$ & $6.39 \pm 1.01^{\mathrm{a}}$ & $5.31 \pm 0.99^{\mathrm{b}}$ \\
acceptability & 20 & $6.83 \pm 0.97^{\mathrm{a}}$ & $5.38 \pm 1.03^{\mathrm{b}}$ & - & - \\
\hline
\end{tabular}

${ }^{1)}$ Mean \pm SD ( $\mathrm{n}=40$ ). Means with different superscripts within the row are significantly different at $p<0.05$ based on Duncan's multiple range test.
에 따른 변화가 적었으며, 저온저장 20 일까지는 맛의 기호 성이 저장 초기와 동일한 수준으로 확인되었다. 전반적 기 호도의 경우 저장 초기 6.83점의 관능평점을 나타내었으나, 저온의 경우 저장 30 일에, 상온의 경우 저장 10 일에 각각 유의적으로 감소하였다 $(\mathrm{p}<0.05)$. 이상의 결과, 상온저장 시 료 10 일째의 관능적 품질은 저온저장 30 일째의 품질과 유사 한 수준이었으며, 상품적 가식한계점인 5점을 기준으로 할 때, 전반적인 상품성 유지기간은 저온저장의 경우 30 일, 상온저장의 경우 약 10 일로 확인되었다.

\section{저장에 따른 품질인자 확인}

Valencia 오렌지의 저장 중 이화학적 특성과 전반적 기호 도 간의 상관관계를 분석한 결과는 Table 4와 같다. 물리적 특성 중 중량감소율과 껍질 및 과육의 전반적 색차는 기호 도와 음의 상관관계를 나타내어, 저장에 따라 무게가 감소 하고 색이 변할수록 기호도가 감소함을 알 수 있었다. 한편 껍질 두께, 과일/과육의 경도 및 껍질의 $\mathrm{b}$ 값은 기호도와 양의 상관관계를 나타내어, 저장 동안 오렌지 껍질의 두께 가 두껍고, 단단하며, 노란색을 띨수록 기호도가 높아짐을 확인할 수 있었다. 오렌지의 물리적 특성 중 경도는 기호도 와 가장 높은 상관관계 $(\mathrm{r}=0.7979)$ 를 나타내었다. 오렌지의 화학적 특성은 전반적 기호도와 모두 양의 상관관계를 나타 내었고, $\mathrm{pH}$ 를 제외한 항목의 상관계수는 물리적 특성에 비해 높은 것으로 확인되었다. 특히 가용성 고형분 및 비타 민 C 함량은 0.9453 및 0.9104의 높은 상관계수를 나타내어, 이들의 함량이 높으면 단맛과 신맛이 증가하여 오렌지의 기호도에 영향을 주는 것으로 확인되었다. 저장에 따른 이 화학적 특성과 기호도 간의 상관계수는 대부분 저온보다 상온에서 더 높게 확인되었고, 이는 상온에서의 품질변화 가 더 많이 일어난 이유로 사료되었다. 이상의 결과, 저장에 따른 Valencia 오렌지의 여러 품질인자는 기호도와 높은 상관관계를 나타내었고, 특히 가용성 고형분과 비타민 $\mathrm{C}$ 함량은 0.9 이상의 높은 상관계수를 나타내어, 이들을 저온

Table 4. Correlation coefficients ( $r$ ) between quality characteristics and sensory acceptability in Valencia oranges during storage at $4{ }^{\circ} \mathrm{C}$ and $20^{\circ} \mathrm{C}$

\begin{tabular}{|c|c|c|c|c|c|c|c|}
\hline Temp. & Weight loss & Peel thickness & Fruit hardness & Flesh hardness & $\begin{array}{c}\text { Peel } \\
\mathrm{b} \text { value }\end{array}$ & $\begin{array}{c}\text { Peel } \\
\Delta \mathrm{E} \text { value }\end{array}$ & $\begin{array}{c}\text { Flesh } \\
\Delta \mathrm{E} \text { value }\end{array}$ \\
\hline $4^{\circ} \mathrm{C}$ & $-0.8655^{1)}$ & 0.7695 & 0.8078 & 0.8077 & 0.6336 & -0.6263 & -0.6828 \\
\hline $20^{\circ} \mathrm{C}$ & -0.7800 & 0.8768 & 0.9004 & 0.9147 & 0.8502 & -0.8539 & -0.9780 \\
\hline Total & -0.6679 & 0.7907 & 0.7979 & 0.7916 & 0.6942 & -0.7156 & -0.5890 \\
\hline Temp. & $\mathrm{pH}$ & $\begin{array}{l}\text { Total soluble solid } \\
\text { (TSS) }\end{array}$ & $\begin{array}{l}\text { Titratable acidity } \\
\text { (TA) }\end{array}$ & TSS/TA ratio & Reducing sugar & Vitamin C & $\begin{array}{l}\text { Total phenolic } \\
\text { compouds }\end{array}$ \\
\hline $4^{\circ} \mathrm{C}$ & 0.9494 & 0.9988 & 0.9897 & 0.7086 & 0.6912 & 0.8376 & 0.8188 \\
\hline $20^{\circ} \mathrm{C}$ & 0.2163 & 0.9258 & 0.6007 & 0.9976 & 0.8911 & 0.9885 & 0.9062 \\
\hline Total & 0.4736 & 0.9453 & 0.7031 & 0.8358 & 0.7708 & 0.9104 & 0.8023 \\
\hline
\end{tabular}

${ }^{1)}$ Significant at $\mathrm{p}<0.05$. 
및 상온 유통 중인 Valencia 오렌지의 선택을 위한 주요 품질지표로 제시될 수 있었다.

\section{요 약}

수입 오렌지 중 Valencia 품종의 신선도 유지기간에 대한 기초자료를 확보하고자, 저온 $\left(4^{\circ} \mathrm{C}\right)$ 및 상온 $\left(20^{\circ} \mathrm{C}\right)$ 의 저장온 도가 오렌지의 품질 특성에 미치는 영향을 평가하고 이와 관련된 품질인자를 확인하였다. 오렌지의 경도는 저장 10 일부터 저장온도에 상관없이 감소하였으며, 과육보다 껍질 에서 큰 폭으로 확인되었다. 가용성 고형분 함량과 적정산 도는 저온저장의 경우 30 일에, 상온저장의 경우 10 일부터 유의적으로 감소하였고, 당/산비는 저장 중 차이를 보이지 않았다. 비타민 C 함량은 저온저장 20 일 및 상온저장 10 일 부터 각각 유의적으로 감소하였고, 총 페놀함량은 저장 10 일부터 감소하였다. 맛에 대한 관능평점은 색과 향의 평점 에 비해 저장기간에 따른 영향이 작았으며, Valencia 오렌지 의 경우 저온저장 30 일째의 품질이 상온저장 10 일째와 유 사한 것으로 확인되었다. 저장 중 이화학적 특성과 전반적 기호도 간의 상관관계를 분석한 결과, 가용성 고형분과 비 타민 C 함량은 0.9 이상의 높은 상관계수를 나타내어 저온 및 상온 유통 중인 Valencia 오렌지의 선택을 위한 주요 품질인자로 제시될 수 있었다.

\section{감사의 글}

본 연구는 농림축산식품부 수출전략기술개발사업에 의 해 이루어진 것으로 이에 감사드립니다.

\section{References}

1. Moulehi I, Bourgou S, Ourghemmi I, Tounsi MS (2012) Variety and ripening impact on phenolic composition and antioxidant activity of mandarin (Citrus reticulate Blanco) and bitter orange (Citrus aurantium L.) seeds extracts. Ind Crop Prod, 39, 74-80

2. Kyung EJ, Kim KH, Yook HS (2014) Quality characteristics of gamma irradiated-imported orange during storage. Korean J Food Nutr, 27, 31-42

3. Jo D, Yoo SY, Park JH, Gao Y, Kim SG, Lee JY, Kwon EJ, Kwon JH (2014) Relationship between the fruit size and the quality properties of imported Valencia oranges. Korean J Food Preserv, 21, 365-372

4. Eaks IL (1970) Respiratory response, ethylene production and response to ethylene of citrus fruits during ontogeny. Plant Physiol, 45, 334-338

5. Lee JH, An HJ, Lee SY, Choi YH, Lim BS, Kang YJ (2009) Changes in quality characteristics of 'Setoka' (Citrus spp.) using different storage methods. Korean J Food Preserv, 16, 644-649

6. Cho YJ, Kim KH, Yook HS (2015) Quality characteristics of low-dose electron beam irradiated-imported navel orange during storage at room temperature $\left(20^{\circ} \mathrm{C}\right)$. J Korean Soc Food Sci Nutr, 44, 455-463

7. Kyung EJ, Kim KH, Yook HS (2014) Quality characteristics of gamma irradiated-imported orange during storage. Korean J Food Nutr, 27, 31-42

8. Cho YJ, Kim KH, Yook HS (2015) Quality characteristics of low-dose electron beam irradiated-imported navel orange during storage at low temperature $\left(3^{\circ} \mathrm{C}\right)$. Korean J Food Nutr, 44, 128-136

9. Hong HD, Kim SS, Kim KT, Choi HD (2001) Quality changes of apple juice concentrates with different storage temperature. Korean J Food Nutr, 14, 28-33

10. Jang KW, Hur JK, Kim SK, Baek YJ (1996) Effects of pasteurization and storage temperature on the quality of orange juice. Korean J Food Sci Technol, 28, 8-14

11. Miller GL (1959) Use of dinitrosalicylic acid reagent for determination of reducing sugar. Anal Chem, 31, 426-428

12. Al-Tayar NGS, Nagaraja P, Vasantha RA, Shresta AK (2012) A spectrophotometric assay method for vanadium in biological and environmental samples using 2,4-dinitrophenylhydrazine with imipramine hydrochloride. Environ Mont Assess, 184, 181-191

13. Singleton VL, Rossi Jr JA (1965) Colorimetry of total phenolics with phosphomolybdic-phosphotungstic acid reagents. Am J Enol Vitic, 16, 144-158

14. Kim HS, Park HN, Kim Y, Kim KO (2005) How can we conduct sensory evaluation effectively? Korean J Food Sci Ind, 38, 2-7

15. SAS (1998) SAS User's Guide: Statistics, 3th ed, SAS Institute Statistical Analysis System, Cary, NC, USA

16. Yang YT, Song SC, Kim SH, Kim JY, Koh JS (1997) Cold storage characteristics of early variety of Citrus unshiu produced in Cheju with various treatments. J Korean Soc Agric Chem Biotechnol, 40, 117-122

17. Kim SH, Lim JH, Koh JS (2002) Quality changes of satsuma mandarin during storage by storage warehouse. Korean J Food Preserv, 9, 131-136

18. Kim BS, Lee HJ, Park HW, Cha HS (2003) Effect of 
respiration and transpiration rates on the weight loss of various fruits (peach, apple, pear, persimon, mandarin). Korean J Food Preserv, 10, 142-146

19. Koh JS, Yang YT, Gang SS (1997) Quality characteristics of early varieties of Citrus unshiu collected at different packing houses as cultivation area in Cheju. Korean $\mathbf{J}$ Postharv Sci Technol, 4, 53-59

20. Lee SH, Kim JH, Jeong HC, Koh JS (2007) Changes in the quality of Hallabong Tangor (Citrus kiyomixponkan) with growth stage and temperature pretreatment conditions. Korean J Food Preserv, 14, 565-570

21. Yang JW, Choi IS, Lee JH, Cho CW, Kim SS (2012) Change of physicochemical properties and hesperidin contents of Jeju processing citrus fruits with the harvest date. Korean J Food Preserv, 19, 652-658
22. Ackeman J, Ficher M, Amado R (1992) Changes in sugars, acids, and amino acids during ripening and storage of apples (cv. Glockenapfel). J Agric Food Chem, 40, 1131-1132

23. Kubola J, Siriamornpun S (2011) Phytochemicals and antioxidant activity of different fruit fractions (peel, pulp, aril, and seed) of Thai gac (Momordica cochinchinensis Spreng). Food Chem, 127, 1138-1145

24. Lee MY, Yoo MS, Whang YJ, Jin YJ, Hong MH, Pyo YH (2012) Vitamin C, total polyphenol, flavonoid contents and antioxidant capacity of several fruit peels. Korean J Food Sci Technol, 44, 540-544

25. Koh JS, Kim WT, Lee SY, Kim JY, Kang CH (1998) Effects on the storage life of satsuma mandarin by the pretreatment at various temperatures. Agri Chem Biotechnol, 41, 228-233 